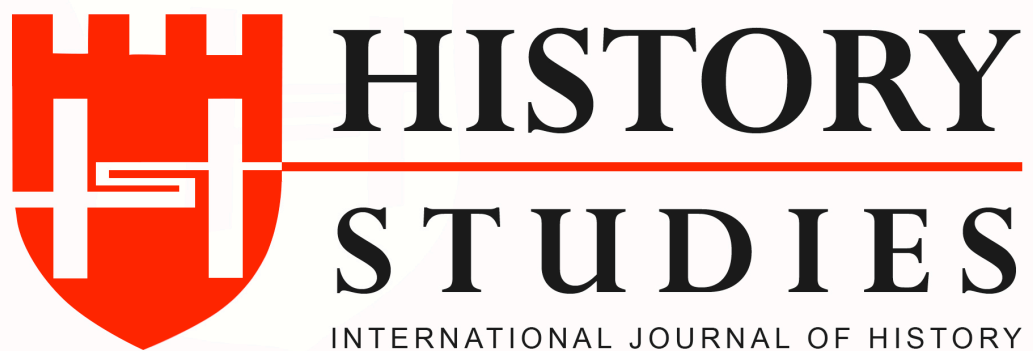

ISSN: 13094173 (Online) 1309 - 4688 (Print)

Volume 11 Issue 3, June 2019

DOI Number: 10.9737/hist.2019.742

Araştırma Makalesi

Makalenin Geliş Tarihi: 14.02.2019 Kabul Tarihi: 25.02.2019

Atıf Künyesi: Hayati Aktaş, "İngiliz ve Amerikan Belgelerinde Samsun'un Bombalanması Olayı ve Pontus Meselesi”, History Studies, 11/3, Haziran 2019, s.827-838.

\title{
İngiliz ve Amerikan Belgelerinde Samsun'un Bombalanması Olayı ve Pontus Meselesi
}

\section{The Bombardement of Samsun in English and American Documents and Pontus Issue}

\author{
Prof. Dr. Hayati Aktaş
}

ORCID No: 0000-0001-8474-8590

Akdeniz Üniversitesi

\section{Özet}

Birinci Dünya Savaşı ve Milli Mücadele döneminde Samsun ve çevresi 1920 Ağustos'unda Sovyet Rusya ile yapılan protokolden sonra Anadolu'ya yardım gelmesi noktasında kritik bir öneme sahip olmuştur. Batum'dan Sinop'a kadar olan Karadeniz sahil şeridi Yunanlıların hayalini kurdukları Pontus Cumhuriyeti fikrinin odak noktası olması sebebiyle Yunan gemileri mütarekeden sonra Karadeniz'de Türk sahil șeridine abluka uygulamalarına katılmış ancak Türk gemilerini yakalamada başarılı olamamıştır. Yunan güçleri daha sonra bir yandan bölgedeki Rumlara silah ve cephane sağlarken diğer yandan bölge halkını yıldırmak amacıyla Türk limanlarını bombalamaya başlamıştır. Milli Mücadeleye silah ve cephane sevkiyatında önemli bir rol oynayan Samsun ise 7 Haziran 1922 tarihinde Yunan donanmasının bombardımanına maruz kalmış ve Yunan askeri unsurları bu hamle ile Batı Anadolu'da istediği başarıyı sağlayamayan Yunan ordusunun mevcut pozisyonunu korumasına yardımcı olmayı ve Türk taarruzunun başlamasının beklendiği bu dönemde, Samsun'dan yapılacak silah ve cephane naklini önlemeyi amaçladığı anlaşılmıştır. Ayrıca Samsun'a bir Yunan çıkarması yapıldığı süsü vererek Samsun ve çevresindeki Pontusçuları kışkırtmak, Türkleri moral yönünden çökertmek gibi beklentilerde söz konusu olmuştur. Ancak bu gelişmeler karşısında İngiliz Hükümetinin tutum ve davranışlarının olayları ya bilmezlikten gelmek, yada duyarsız davranmak olduğu dikkate değer başka bir husustur.

Anahtar Kelimeler: I. Dünya Savaşı, Samsun, Karadeniz, Yunan Donanması, Pontus Meselesi

\begin{abstract}
During the First World War and the National Struggle, Samsun and its environs had a critical importance in transfering the aid to Anatolia after the protocol with Soviet Russia in August 1920. The Black Sea coast from Batumi to Sinop was the focal point of the idea of the Pontus Republic, in which the Greeks had dreamed of, and thus the Greek ships joined the blockade of the Turkish coastline in the Black Sea after the armistice, but they were not successful in capturing Turkish ships. While the Greek forces then provided weapons and ammunition to the Greeks in the region, they began to bomb the Turkish ports in order to intimidate the people of the region. Samsun, which played an important role in the arms and ammunition delivery for the National Struggle, was bombarded by the Greek navy on June
\end{abstract}


7, 1922, and the Greek military elements were expected to help the Greek army to maintain its current position in Western Anatolia and to prevent the transport of weapons and ammunition from Samsun when the Turkish offensive was predicted. In addition, by making look like that there was a Greek military landing in Samsun, it was aimed at provoking the surrounding region to provoke the supporters of the idea of Pontus and demoralising the Turks. However, it is noteworthy that the British Government's attitudes and behaviors were either ignorant or insensitive in the face of the events.

Keywords: World War I., Samsun, Black Sea, Hellenic Navy, Pontus Issue

Birinci Dünya Savaşı ve Milli Mücadele döneminde Samsun ve çevresi de, işgaller ve ihanetlerle karşılaşmıştı 1920 Ağustos'unda Sovyet Rusya ile yapılan protokolden sonra bu ülkeden Anadolu'ya yardım gelmeye başlamıştı. Gelen yardımlar ya doğrudan ya da Trabzon aracılığıyla İnebolu, Samsun ve Akşehir ile çıkarılıyor, oradan da Batı Cephesi'ne taşınıyordu. Bu bakımdan Samsun Karadeniz'in Anadolu kıyılarından Anadolu içlerine açılan en önemli kapılarından biri konumundaydı. Ancak Samsun, bütün Karadeniz Bölgesi ile birlikte Birinci Dünya Savaşı içinde ve Mondros Mütarekesi'nin imzalanması üzerine başlayan mütareke döneminde yeni bir tehdit ile karşı karşıya kaldı: "Pontus Meselesi". Yöredeki Rumlar, Fener Rum Patrikhanesi'nin organize ettiği ve bölgede kurulan Pontus Terör Örgütünün yürüttüğü katliamlarla, ilkçağlarda bu bölgede İran asıllı bir aile tarafindan kurulan Pontus Krallığı ( M.Ö. 298, M.S. 63)'nı dirilterek “megali idea”yı gerçekleştirmek sevdasına kapıldılar. ${ }^{1}$

Bu dönemde bölgede görevli olan Amerikalı bir general, Amiral Bristol'un hazırladığ ve 2 Haziran 1921 tarihinde İstanbul'dan Washington' daki Amerikan Dışişlerine gönderilen bir raporda şu ifadeler yer almaktaydı: "Daha önceki telgrafımda rapor edildiği üzere Rumların kendi nüfuslarının çoğunluk olmadığını kabul ettikleri Pontus'ta, ateşkesten bu yana hem Osmanlı Rumları hem de Helenik Rumlar Türk yetkililerine karşı isyan ve ayaklanma içerisindedirler. Ayrıca bu kampanya Venizelos dahil Yunan resmi görevlileri tarafından desteklenmektedir. ${ }^{2}$

Oysa daha 1919 yılında Yunanistan'da yapılan bir toplantıda propaganda çalışmaları başlamış bulunuyordu. " Yunanistan'da geçici olarak ikamet eden Anadolu Rumlarının Genel Meclisi, bağımsız Yunanistan'da sığınmacı olarak bulunan Anadolu'nun tüm Rum nüfusunu temsilen bir araya gelmiş ve 23 Şubat-8 Mart 1919 tarihinde bir konferans düzenlenmiştir.

Burada alman karar, Anadolu'nun Yunanistan Krallığ ile birleşmesidir. Bu, tüm Rum nüfusun tek arzusudur. Atina'da yapılan açık hava mitingi, plebisitler, ve kongreler ile müttefik devletlerin halkına hükümetlerine bu birleşme isteği bildirilecektir. Etkin bir şekilde Pontus'tan Aydın ve Bursa'ya kadar Anadolu'da sadece tarihi ve etnolojik yerler değil, mevcut nüfus çoğunluğunun da Rum olduğu vurgulanacaktır.

Alman karar Yunanistan Başbakanı Venizelos ile, Paris, Londra ve New York'taki o önemli gazetelere telgrafla bildirilecektir. Pan Micraasiatic Kongresi Yönetim Kurulu” ${ }^{3}$

İşte; kurulması planlanan Pontus Cumhuriyeti için Yunanistan'ın yaptığı propaganda çalışmalarına yönelik bir başka önemli rapor, İstanbul'daki Amerikan Konsolosu Ralph Chesbrough 5 Ağustos 1919 tarihinde İstanbul'dan Amerikan Dışş̧lerine şu raporu

\footnotetext{
Ali Güler, Sorun Olan Yunanlılar ve Rumlar, Ankara, 2003, s. 129.

2 US ARCHIVES NARA (National Archives and Research Administration of The United States) m 363, Roll3; 767-68/98

3 UK ARCHIVES (The National Archives) FO 608/89
}

\section{History Studies}


gönderiyordu: "Yunan propagandası, Yunan kontrolü altında bağımsız bir Pontus Cumhuriyeti kurma fikri yaratmak için hala bu bölgede faaliyettedir. Bu Cumhuriyet Rum etkisinin ve Rumların hakim olduğunun tartışıldığı bölge olan Batum'dan Sinop'a kadar olan Karadeniz kıyısını ihtiva etmektedir. Rumlar kıyı hattı üzerindeki tutku ve ihtiraslarını bozacağı için Karadeniz'de bir liman kentini Ermenilere vermek taraftarı değildir. işte Yunan propagandası bu fikri desteklemek ve yaymak gayreti içerisindedirler. Yunan torpido gemileri bu amaca hizmet etmek üzere Karadeniz kıyılarında bulunmaktadır. Birçok Yunan Kızılhaç üniteleri kuruldu. Böylece Yunan kaynaklarından büyük miktarlarda paralar bu birimlere akıyordu. Bütün bu yapılanlar Rumlar arasında potansiyel bir devrim ruhunu yaratmak içindir. Birçok Rum'un hatta Elen (Yunan) vatandaşların bile Karadeniz'in bu limanına gelmelerinin sebebi bu amaç içindir. ${ }^{4}$

Pontus örgütünün amacı eski Romalıların "Euksinos Pontus" dedikleri ve Batum'dan itibaren Trabzon, Ordu, Giresun, Samsun sahil vilayetleri ile içeride Amasya ve Sivas vilayetlerinin bir kısmını içine alan yerleri Sinop'a kadar genişleterek Yunanlılaştırmak, buraları Türk boyunduruğundan kurtararak, ileride Yunanistan ile birleştirmek üzere eski çağlardaki Pontus Krallığı'nı canlandırarak müstakil bir "Pontus Devleti” meydana getirmekti. ${ }^{5}$

Bu örgütün içerideki faaliyetleri ile birinci derecede sorumlu olanlar şunlardı: Trabzon metropoliti Hrisantos, Samsun metropoliti Germanos ve Samsun'da Reji fabrikasi müdürü Takomonidis $^{6}$ ile Samsun'un Rum piskoposu Damianos burada bir Pontus Cumhuriyeti oluşturmak için çalışan en önemli yetkilidir.

Samsun'daki Rum piskoposu Damianos'un Pontus Cumhuriyeti oluşturulmasıyla ilgili faaliyetleri hakkında bir rapor hazırlayan ve bu raporu 15 Mayıs 1919'da Samsun'dan İngiliz Dışişlerine gönderen Kraliyet Donanması Komutanı Heathcote Smith'in verdiği bilgiler oldukça ilginçtir: "Başpiskopos Domianos Yeni Pontus Rum Cumhuriyetinin Rize ve Trabzon'dan Sinop'a kadar 80-150 millik bir hinterlandı kucaklayarak uzanması gerektiğini ifade ediyor. Avrupa'nın ve özellikle bu bölgeyi ziyaret edeceklerine inandığı Amerikan Komisyonu'nun dikkatini çekmek için, Başpiskoposun amacı ve hırsı Güney Rusya'daki 500.000 Rum'u bir an önce buraya dönmeye ikna etmektir. (Bu Rumların beşte biri daha önce hiç Türkiye'de bulunmamıştır). Başpiskoposun bir amacı da, bölgede karışıklık çıkarmak için Rum eşkıyaları teşvik etmek ve yüreklendirmektir. Böylece Pontus sorunu daima ön planda tutulacaktır.

Sayıları 2000 ila 4000 arasında verilen bölgenin dağınık Rum köylerindeki bu Rum eşkıyalar, Rus ilerleyişi sırasında oldukça etkili çeteler oluşturmuşlardır. Bunların amacı kendilerinin "Pontus Cumhuriyeti Ordusu", itlaf devletleri ile birlikte savaşan bir müttefik devlet olarak anılmaktır.

Başpiskopos bir ikilem içerisindedir. Bir taraftan Pontus Cumhuriyeti’nin kurulduğunu görmek için yanıp tutuşurken ve bunun için Pontus kuvvetlerinin Rumları savunacak kadar güçlü olduğunu söylerken, diğer taraftan da kendi cemaatine yönelik cinayetlerin olduğunu ve kendilerinin güvensizliğini ve korunma ihtiyacını öne sürmektedir. Böylece Başpiskopos sürekli olarak kendisini yalanlamakta ve tekzip etmektedir. Burada sürekli karışıklık ve

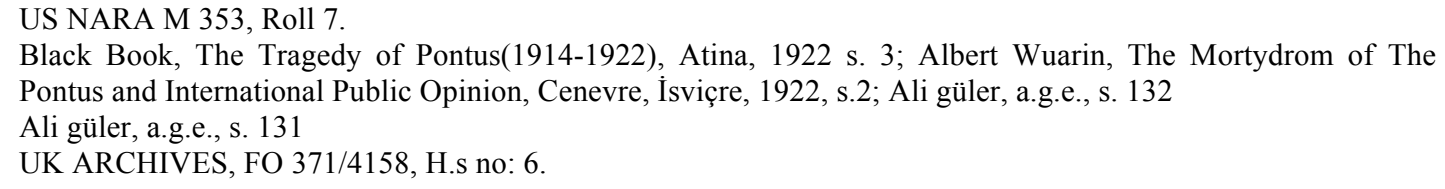


düzensizlik çıkaran kişi kendisidir. Ben onun geri çağrılmasını ve yerine 1 lımlı birinin gönderilmesini tavsiye ediyorum.",

Mütarekeden itibaren Karadeniz'de aralıksız faaliyette bulunan İngilizler, bir süre sonra Yunanistan'1 da harekatlarına ortak etmeye başladı. Esasında Yunanistan Mondros Mütarekesi sonrasında İtilaf Devletleri donanması ile Boğazlara girmiş, daha sonraları da yine onlarla beraber Karadeniz'de faaliyetlere girişmiş ve Batı Anadolu'da Milli kuvvetlere karşı her harekete geçişinde, Karadeniz'de abluka uygulayarak Türk gemilerini aramıştı. Ama Yunan Donanması'nm Karadeniz'e yönelik yoğun faaliyeti 1920 yılının ortalarından itibaren başlamaktadır. Zira bu dönemde önce Kafkaslardan, sonra da Batum'dan ve Samsun'dan çekilen İngilizler, Karadeniz'de eksilen kuvvetlerini Yunana Donanması ile kapatmaya başlamışlardı.

1920 yılından itibaren bütün Karadeniz'de askeri, ticari gemiler ve yolcu gemilerine uygulanan kontrol faaliyetleri, îngiliz ve Fransızların denetiminden büyük oranda Yunan donanmasının eline geçmiştir. Öyle görünüyor ki, Milli kuvvetler ağırlığını hissettirdikçe, Karadeniz kıyılarındaki İtilaf devletlerin kontrolü yerini Yunana savaş gemilerine bırakıyor ve onlara zaman zaman yardımcı oluyordu. ${ }^{10}$

Yunanistan 21 Mart 1921 tarihinde Türk kıyılarına abluka ilan etti. Aslında Yunan donanması yalnızca bu abluka şartlarını yerine getirmekle vazifeli değil; aynı zamanda Karadeniz'deki Pontus Rumlarına yönelik yardım ve propaganda faaliyetlerinden de sorumluydu. Nitekim Yunanistan'ın Karadeniz'de abluka ilanından hemen önce, îkinci Londra Konferansında ve îkinci İnönü Savaşı'nın yapıldığı sıralarda Lloyd George'un Yunan delegasyonuna saldırı sonuçsuz kalırsa ne yapacaklarını sorduğunda aldığı cevap; "Eğer Ankara İtilaf Devletleri'nin kararlarını kabul etmeyecek olursa, Yunanistan Pontus sahillerine asker çıkararak yerli Rum ve Ermenilerin de yardımı ile Samsun'dan Sivas'a ilerleyecektir." şeklinde olmuştur. ${ }^{11}$

Bu arada İngiliz cephane ve mühimmatı Trabzon'dan Samsun'a getirilmekte ve Rum piskoposun uygun gördüğü çeşitli Rum köylerine dağıtılmaktaydı. Piskopos böyle durumlarda çok önemli rol oynamaktadır. ${ }^{12}$

Yunan donanması nakliyat yapan Türk gemilerini yakalamada başarısız olunca da çareyi, limanları bombalamakta bulmaktaydı. Trabzon, Samsun ve İnebolu, Yunan bombardımanına maruz kaldı. İngilizler Yunan donanmasının Karadeniz'deki bombardımanını hem teşvik etmekte hem de resmen katılmasa da üslerini kullandırarak destek vermekteydi. ${ }^{13}$

Yunan savaş gemileri 1921 yaz döneminde Karadeniz kıyılarını bombaladılar. Bu savaş gemilerinin oluşturulacak bir Rum Pontus devrimine katkıda bulunmak için karaya silah ve cephane indirdikleri rapor edildi. ${ }^{14}$

Bombalama tarihleri şu şekildedir:

7/6/1921 Ereğli

30/6/1921 İnebolu

UK ARCHIVES, FO 371/4158, H.s no: 6.

9 Mehmet Okur, Milli Mücadele'de Karadeniz Bölgesine Yönelik îngiliz Faaliyetleri, Ankara, 2006, s. 175.

${ }^{10}$ Okur, a.g.e, s. 176.

${ }^{11}$ Bilal Şimşir, İngiliz Belgelerinde Atatürk III, Ankara, 1979, s. 170-171; Okur, a.g.e, s. 176.

${ }^{12}$ US ARCHIVES NARA m 353, Roll 9, no: 299, Amiral Bristol'ün Dişişleri Bakanlığına yazdığı rapor.

${ }^{13}$ Okur, a.g.e, s. 177.

${ }^{14}$ UK ARCHIVES, FO 371/7878, War Office, E 5674/19/44 


\section{0/7/1921 Trabzon}

\section{1/7/1921 Samsun}

İngiliz Yüksek Komiseri Dışişleri Bakanlığı'na bir telgraf çekerek, bu bombalama olaylarını kastetmiş ve açık limanların top ateşine tutulmasına karşı, majestelerinin hükümetinin protestoda bulunması gerektiğini söylemiştir. ${ }^{15}$

Karadeniz'de 1919'dan 1922'ye kadar arama ve bombardıman faaliyetlerine katılan Yunan gemileri şunlardi:

Kilkış, Lemnos, Averof, Panther, Jerax, Leon, Aetos, Keravanos, Neaganea, Thlella, Sfendoni, Lonchi, Nophratoussa, Doxa, Apsis, Niki, Velas, A1glı, Thetis, Daghne, Arethose, Alycon ve Boris.

Yunanistan bütün çabalarına ve İngilizlerin yardımlarına rağmen, Karadeniz limanlarını bombalama faaliyeti dışında başarısız oldu ve Batı Cephesi'ne silah taşınmasına engel olamadı. Bu durumu, İstanbul Müttefik Orduları Başkumandanı General Harrington da görmüş ve Savunma Bakanlığı'na rapor etmişti. Harrington'a göre bu ablukaya rağmen, Rusya'dan, Samsun'a, Trabzon'a ve diğer bazı şehirlere Temmuz 1921 sonuna kadar 800 ton askeri malzeme gelmişti. ${ }^{16}$

Birleşik Devletler Yüksek Komiseri Amiral Mark Bristol Yunan savaş gemisi Kılkış'ın Karadeniz'de saldırılar yaptığını ve bu aptalca hareketin neticesinin yaklaşı 1000 kadar Osmanlı Rum'unun acil olarak sınırdışı edilmesi olduğunu bildirmiş ve raporunda 1921 Temmuz'unda iki İngiliz destroyerinin Samsun'a geldiğini; geliş nedeninin ise güya ticareti yeniden başlatmak olduğunu, fakat asıl amacının Anadolu'da Bolşevik faaliyetler olduğunu belirtmiştir. Bristol 30 Temmuz'da yaklaşık iki milyon dolar değerinde Sovyet altının Samsun'da karaya indirildiğine dair bilgiler aldığını raporunda öne sürmüştür? ${ }^{17}$

Amerikan Doğal Tarih Lisesi Müdürü ve değerli bir Jeolog olan Dr. Bornum Brown Standart Oil şirketi adına 1921 yılında iki ay kadar Türkiye'de bulunmuştu. Onun görevi Hükümet yetkilileriyle buluşmak ve onlarla hem temsilcilik hem de bayilik hususlarını görüşmek idi. Türkiye'deki çalışmalarından sonra gittiği Londra'da Amerikan Başkonsolosuna ayrıntılı bir rapor sunmuştur. ${ }^{18}$

Elde ettiği bilgilerin Amerikan Dışişleri Bakanlığı'na ulaştırılması amacıyla Londra'da Başkonsolos ile görüşen Dr. Brown'ın anlattıklarına göre Yunan Deniz Kuvvetleri, siyasi ya da askeri her ne amaçlarla olursa olsun Karadeniz boyunca yoğun nüfuslu, meskun bölgeleri devamlı ateş açarak taciz ediyordu. Dr. Brown'a göre bir Yunan Deniz Filosu dört ayrı zamanda ve oradaki müttefik askeri komutanlardan herhangi bir uyarı ve izin almaksızın Karadeniz kıyıları boyunca savunmasız halka ateş açmak için İstanbul'dan ayrıldı. Bu bombalamaların kıyıya çıkışı desteklemek ya da kıyıdaki herhangi bir askeri girişimi kolaylaştırmak için yapılmadığı apaçık ortadadır. Bu bombalamalar sadece ve ancak şiddet kullanarak yıldırma şeklidir. Bu bombalamalar ${ }^{19}$ dan direkt etkilenecek olan sadece Rumlar değil buralardaki Türk yerli nüfustur.

Batı Anadolu'nun Yunan işgaline uğraması her zaman Pontus'un Osmanlı Rumlarını ya otonomi ya da Yunanistan'la birleşme için daima kışkırtıcı ve tahrik edici bir unsur

${ }^{15}$ FO 371/7878 War Office, E 5674/19/44

${ }^{16}$ Şimşir, a.g.e, s. 580.

${ }^{17}$ US ARCHIVES NARA M 363, Roll 3, 767-68/143 no:401.

${ }^{18}$ US ARCHIVES NARA M 363, Roll 3, 767-68/142 no:11673.

${ }^{19}$ US ARCHIVES NARA M 363, Roll 3, 767-68/142 no:11673. 
olmuştur. İngilizlerin İstanbul'daki Ordu karargahında hazırlanan bir raporda 1921 ve 1922 'de Pontus'ta Rumların isyan hareketleri ve bunları bastırmak için Türklerin aldığı önlemler anlatılırken; son zamanlardaki sınırdışı etme olaylarının Türk yetkililerinin Rum çetelerini önlemede zorluk çekmeleri nedeniyle olabileceği öne sürülmektedir. ${ }^{20}$

Samsun'un iç kısımlarında Rumlar gizli bir şekilde Türklere karşı silahlanmakta ve Rum eşkıyalar tarafından Türklere ait koyun sürüleri çalınmaktadır. ${ }^{21}$

Samsun ve civarında seyreden bunca olaya rağmen 7 Haziran 1922 tarihinde Yunan donanmasının Samsun'u bombardıman etmesi kadar etkili bir olay olmamıştı. Bu bombardıman bir bakıma da Yunan donanmasının Karadeniz'deki son önemli faaliyet olmuştu. ${ }^{22}$

Yunan savaş gemisi Averof, destroyerler eşliğinde 5 Haziran'da Karadeniz'e girdi ve 7 Haziran'da üç saat Samsun'u bombaladı. Bombalamanın amacının bu limandaki cephane stoklarını tahrip etmek olduğu rapor edilmektedir. ${ }^{23}$

Yunan donanmasını böyle bir harekete sevk eden sebepler ise; Batı Anadolu'da istediği başarıyı sağlayamayan Yunan ordusunun artık Anadolu'da ilerlemek değil, tutunmaya çalıştığ ve Türk taarruzunun başlamasının beklendiği bu dönemde, Samsun'dan yapılacak silah ve cephane naklini önlemek, bu şehirdeki silah ve mühimmatı imha etmekti. Ayrıca Samsun'a bir Yunan çıkarması yapıldığı süsü vererek Samsun ve çevresindeki Pontusçuları kışkırtmak, Türkleri moral yönünden çökertmek gibi beklentilerdi. ${ }^{24}$

O sırada Samsun'da Ankara'ya sevk edilmek üzere çok miktarda cephane vardı. Depolar mayın silahıyla doluydu. İskele üzerinde bile yeni gelmiş cephane sandıkları duruyordu. Bununla birlikte Samsun müstahkem veya silahlı bir şehir değildi. Düşmanın böyle bir şehri bombardıman etmesi milletlerarası kaidelere aykırıyd.$^{25}$

Saat 10.00'da Yunan savaş gemisi Averof tan indirilen bir motor limanda bulunan 284 say1lı Amerikan destroyerine gönderildi. Sonra da Yunan motoru Averof a dönerken, Amerikan destroyerinden bir motor sahile doğru gönderildi. Bir Amerikan Yüzbașısı elindeki kapalı zarfı mutasarrıfa vermek istediğini, iskeledeki deniz subayına bildirdi. Dört deniz erinin muhafazasında Amerikan Yüzbaşısı Tümen karargahına gönderildi. Getirmiş olduğu zarfta Yunan Amirali'nin notası bulunuyordu. Bu notada Samsun'un bir açık şehir olmadığı, şehirde mevcut cephanenin meydana çıkarılarak bir askeri heyet huzurunda imhasına imkan verilmesi ve aksi takdirde şehrin bombardıman edileceği bildiriliyordu. ${ }^{26}$

Ankara ile görüşerek talimat alan mutasarrıf nota'ya verdiği cevapta; Samsun'un silahsız açık bir şehir olduğunu ve Devletler Hukukuna göre bombardıman edilemeyeceğini, aksi takdirde Yunan hükümeti'nin mes'ul tutulacağını, dolayısıyla halkın zararına karşılık misilleme yapılacağını bildirdi.

$\mathrm{Bu}$ gelişmeler sürerken Amiral gemisi Averof tan kuru sıkı bir top patlatıldı ve 14,30'da bombardıman başladı. İstanbul'daki İngiliz Yüksek Komiseri Nevile Henderson Dışişlerine yazdığı raporda 20 atış yapıldığını belirtmektedir. ${ }^{27}$

\footnotetext{
${ }^{20}$ UK ARCHIVES, FO 371/7878, E 5674/19/44, War Office.

${ }^{21}$ NARA, C 48, Part 2, Class 805, Volüme 21, Amerikan Konsolosluğu, Samsun, 021.

${ }^{22}$ Rahmi Doğanay, "Milli Mücadelede Samsun'un Önemi ve Samsun Bombardımanı".

${ }^{23}$ FO 371/7883, E. 5839/27/44, Eastern Turkey.

${ }^{24}$ Doğanay, a.g.m, s. 51.

${ }^{25}$ Emrullah Nutku, "Samsun Bombardımanı ve kahramanlık Yarışı”, Yakın Tarihimiz, Cilt IV, Sayı:41, s. 59.

${ }^{26}$ Emrullah Nutku, a.g.m., s. 60FO 371/.

${ }^{27}$ FO 371/7884 E. 6830/27/44.
} 
Bombardımandan sonra meydana gelen kayıplar konusunda İngiliz raporlarına göre gelişmeler şu şekilde idi: Bölgedeki tüccarların eşyaları ile dolu olan gümrük deposu kısmen tahrip olmuştu. Oldukça önemli miktarda benzin ve gaz yağı bulunan petrol deposu (Amerikalılarınki de dahil) zarar görmüştü. Bu yaklaşık 23.000 dolar tutarında bir zarar idi. Ayrıca konak'ta bulunan hükümet binasının yedi odası tahrip olmuştu. Bir Rum'a ait depo ve mallar (yaklaşık 30.000 dolar) tahrip olmuştu. Near East Relief tarafından kiralanan bir garaj üç defa vurulmuştu ve yaklaşık bin dolarlık bir maliyeti olacaktı. Alston tütün şirketinin deposu ve içindekiler yaklaşık 2000 dolarlık bir zarara uğramıştı. ${ }^{28}$

$\mathrm{Bu}$ sırada Samsun'un bombalanması olayına Sovyetler Birliği de tepki göstererek Yunanistan'1 protesto etmiştir. 22 Temmuz 1922'de 162 no'lu Moskova ÎZVESTÎA gazetesinden tercüme edilerek Washington'daki Dışişleri Bakanlığı'na gönderilen bir Amerikan belgesinde Sovyet Hükümeti'nin açıklaması şu şekildedir:

Rusya Hükümeti Anadolu kıyılarının kontrolü ile ilgili olan Yunan gemilerinin aslında askeri bir ablukayı gerçekleştirmekte olduklarını hayretle öğrenmiş bulunmaktadır. Bizim gemilerimiz ve Türk limanlarına gönderilen kargoları müsadere edilmektedir. Samsun'un bombalanması Rusya Hükümeti'ni çok şaşırtmıştır. Zira bu bombardımanlar Rus mallarının olduğu depoları tahrip etmiştir.

Yunan gemilerinin bu operasyonlarına dikkatinizi çekmek suretiyle SSCB Hükümeti,

HISTORY

STUDIES

833

Volume 11

Issue 3

June

2019 gemilerin Çanakkale Boğazından geçişinden sorumlu olan İstanbul'daki müttefik Deniz
Kuvvetleri Komutanlığı'nm Karadeniz'de bulunan Yunan Deniz Kuvvetleri'nin illegal operasyonlarına karşı bir önlem almadığını belirtmektedir. Bu da bölgedeki barışa çok büyük zarar vermektedir.

Cenevre'de Sovyet Delegasyonunca ele alman bir memorandumda İtilaf Devletleri Hükümetleri hem Ankara Hükümeti'ne hem de Rusya Hükümeti'ne Anadolu'da barışın kurulmasına yönelik yardım ve katkıda bulunacaklarına dair öneri sunmuşlardı. Rusya Hükümeti de barışa katkıda bulunmak için elinden gelen her şeyi büyük bir istekle yapmaktadır. Oysa diğer taraftan Anadolu'da barışın sağlanması için teklifte bulunan İtilaf Devletleri Yunanlıların barışı bozan ve yok eden uygulamalarını önlemiyorlar. Bu da Sovyet Hükümetine karşı dostane ilişkileri olan Ankara Hükümeti'nin olduğu kadar bizim menfaatimize de zarar vermektedir.

$\mathrm{Bu}$ bombardıman olaylarını protesto eden Sovyet Rusya Cumhuriyeti Hükümeti îtilaf Devletleri yönetimlerinden Yunanlıların gelecekte böyle düşmanca faaliyetlerde bulunmasını engellemek için daha faal önlemler almasını ümit etmektedir.

Dışişleri Komisyon Yardımcısı: Karakhan ${ }^{29}$

Yunan Savaş gemisi Averofun destroyerler eşliğinde 7 Haziran 1922'de Samsun'u bombalaması olayı hem İstanbul'daki İngiliz Yüksek Komiserliği hem de Atina'daki İngiliz Dışişleri Temsilciliği vasıtasıyla sunulan raporlar ve çekilen şifre telgraflar ile İngiliz Dışişleri Bakanlığına bilgiler verilerek aktarılmıştır. Ayrıca bu husus Parlamentoda gündeme getirilmiş ve soruşturmalara konu olmuştur.

İstanbul'daki İngiliz Yüksek Komiseri Rumbold'un bombalama olaylarından sonra çektiği şifreli telgraflardan bazıları şöyledir:

\footnotetext{
${ }^{28}$ FO 371/788Z E. 6830/27/44/Section 2.

${ }^{29}$ US ARCHIVES NARA, 767-68/269.
} 
“Samsun'un bombalanması gibi olaylar durumu daha da karmaşıklaştırmaktadır. Böyle girişimler durumu çözümlemede başarılı olamaz. Bombalama olayının Pontus'ta' ve diğer yerlerde Hıristiyanlara karşı alman önlemleri provoke etmesi muhtemeldir. Ankara Hükümeti tarafindan Yunanistan'ın geri çekilmesini isteyen protesto yüzünden bilgiler ulaşmaktadır. ${ }^{30}$

Rumbold'un 22 Haziran 1922'de İstanbul'da çektiği 270 nolu telgrafi:

"Dışişleri Bakanlığından aldığım bir nota Ankara Hükümetinin bütün tarafsız misyon şeflerine Paris ve Roma'daki temsilcilere ve bütün müttefiklere protesto bildirilmektedir. Yunan Savaş gemilerinin Samsun'u bombalaması açıkladıktan sonra, bunların İstanbul'a döndüğü ve cephane olarak tekrar Karadeniz'e girdikleri ve birkaç Türk gemisini batırdıktan sonra yine İstanbul'a döndükleri bildiriliyor.

Bu limanın Yunan Deniz filosunca, geçen Mayıs ayında ilan edilen tarafsızlık bildirilerine rağmen bir deniz üssü olarak kullanılması protesto ediliyor.

Ankara Hükümeti bir açık şehir bombalanması olayının Yunan mezalimi için bir delil teşkil ettiğini ve bu durumun Anadolu'da Müslümanlar arasında tahrik edici bir unsur oluşturduğunu öne sürmektedir. $\mathrm{Bu}$ nedenle Yunanlıları boşaltmaları gerektiği ifade edilmektedir. $^{31}$

RUMBOLD Samsun'un bombalanması olayının Ankara Hükümeti'nin Pontusta bir soruşturma komisyonu önerisini kabul etmesini zorlaştıracaktır diyerek, bu durumun Türk görüşünü destekleyeceğini ve azınlıklara baskı yapılmasına yol açacak yeni bir tahrik unsuru olacağını öne sürmüştür. ${ }^{32}$

İngiliz Dişişleri temsilcisi Lindlay'de Atina'dan 16 Haziran 1922'de çektiği telgrafta Samsun'un bombalanması olayını Dışişleri Bakanına aktardığını ancak bakanın bu konuda bilgisi olmadığını ve konuyu derhal Bakanlar Kurulu'na getireceğine dair söz verdiğini söylemektedir. ${ }^{33}$

19 Haziran 1922'deki İngiliz Parlamentosu'nda yapılan görüşmelerde yaşanan gelişmeler İngiliz belgelerinde şöyle geçmektedir:

"Mr. Aubrey Herbert: Dışişleri Bakanlığı müsteşarına Yunan Donanması tarafından Samsun'un bombalanmasına yönelik bilgi verildi mi? Savaş malzemeleri dışında bir tahribat oldu mu? Boğazların ve Çanakkale Boğazı'nın tarafsızlığı Müttefik Güçler tarafından ilan edildi mi? Yunan filosunun bu hareketi ve müttefiklerin onayı için bir açıklama yapma hususunda bir hazırlık var midır?

Dışişleri bakanlığı adına Mr. Harmsworth: Sorunun ilk kısmının cevabı olumludur. Saldırının amacının Rusya'dan bu limana getirilen savaş malzemelerinin tahrip edilmesine yönelik olduğu görülüyor. İngiliz hükümetinin savaş dışı mal mülkün tahrip edilmesine yönelik bir bilgisi yoktur.

Müttefik Devletlere Samsun'un bombalanmasına yönelik Yunanistan'ın niyet ve amac1 ile ilgili bilgi verilmemiştir. Ve onlardan izin alınmamıştır.

Mr. Herbert: Eğer silahlı güçlerin böyle tarafsız bir bölge olarak adlandırılan bir yere girmelerine müsaade edilirse o zaman "tarafsızlı" ne demektir?

\footnotetext{
${ }^{30}$ FO 371/7883, no: 271.

${ }^{31}$ FO 371/7883 E, 6311/27/44

${ }^{32}$ FO $371 / 7884$ E, $5840 / 27 / 44$

${ }^{33}$ FO $371 / 7883$ E, $6101 / 27 / 44$ no: 219
} 
Mr. Harmsworth: Ben gerçekten olayla ilgili uygun yorumu yaptım. Eğer isterse ve gerek duyarsa daha fazla bilgi ve aydınlanma için daha başka bir soru önergesi verecektir.

Mr. Malone: Kullanılan bombaların İngiliz bombaları olduğu gerçek midir?

Mr. Harmsworth: Bunun ihtimal dışı olduğunu düşünmeliyim. Bilgim yoktur. ${ }^{34}$

Parlamento soruşturmasının 19 Haziran 1922 tarihli oturumunda, Kıdemli Yüzbaşı Kenworthy majestelerinin Hükümeti'ni Samsun'un ve Karadeniz'in diğer kasabalarının bombalanması hususunda bilgileri olup olmadığını sordu ve Dışişleri Sekreteri Mr. Harmsworth ne Samsun ne de diğer kasabaların bombalanmasına dair bir bilgi olmadığını ve Mr. Herbert'in 19 Haziran' daki sorusuna verilen cevaba eklenecek bir şey olmadığını söyledii. ${ }^{35}$

21 Haziran 1922 tarihinde Kıdemli Yüzbaşı Kentworthy bu defa parlamentoda Yunanistan'ın Türklerin kıyı kasabalarını bombalamak için Karadeniz'e savaş gemilerini göndermesi hususunda Yunan hükümetinin bu hareketine karşılık majestelerinin hükümetinin yaklaşımlarının ne olduğunu ve bu konuda Yunan hükümetiyle bir iletişim kurulup kurulmadığını sordu.

Dışişleri Bakanlığı sekreteri Mr. Cecil Harmsworth, bu olayın barış şansını bozan üzücü bir hadise olduğunu ve bu nedenle önlemler aldıklarını açıklayarak, Yunan hükümetine böyle olayların tekrarlanmaması ümidiyle gerekli görüşleri aktardıklarını söyledi.

Yüzbaşı Kentworthy ise teşekkür ettikten sonra "Acaba bu gemilerin boğazlardan geçişleri kontrol edilemez miydi?" diye sordu. Mr. Harmsworth'un cevabı: "Bu konuda ilave bir şey söyleyemem oldu." 36

Yine Parlamento soruşturmaları kapsamında 22 Haziran 1922'de yapılan oturumda gerçekleşen görüşmelerde bu kez ilginç bulguların ortaya çıktığı görülmektedir. Zira İngiliz arşiv belgelerinde görüldüğü üzere parlamentodaki sorulara verilecek cevapları önceden tasarlayan Dışişleri Bakanlığı'nm iki farklı taslak hazırladığını görmekteyiz.

Belgelerde 22 Haziran görüşmelerin tutanakları şöyledir:

“Kenthworthy, Majestelerinin hükümetinin Samsun'un ve Pontus'un diğer kasabalarının bombalanması hususunda bir bilgisi var mı diye sordu. Acaba sivillere ve sivil yerleşimlere zarar verilmiş miydi? Acaba Amerikalı ya da Avrupalı bir vatandaş kaybı var mıydı? Ya da mal kaybı olmuş muydu?

Dışişleri Bakanlık Sekreteri Harmsworth: Diğer yerlerin bombalanması ile ilgili resmi bir bilgi yoktu. Ancak Samsun'u biliyorlardı. Hem İstanbul hem Ankara hükümetinden de can ve mal kaybı için protestolar vardı. Ancak majestelerinin hükümetinin bilgisi yoktu. ${ }^{37}$

Harmsworth Ankara'daki Büyük Millet Meclisinden ve İstanbul'daki hükümetten hem can hem de mal kaybı olduğuna dair protestolar aldıklarını, ancak detayları bilmediklerini söylemektedir. Oysa aynı arşiv belgesinde Dışişlerinin hazırladığ ikinci bir cevap taslağı metni vardır ve aşağıdaki gibidir:

"Alternatif Cevap:

Yüzbașı Kenthworthy’ye cevap taslağ 1

\footnotetext{
${ }^{34}$ FO 371/7883 E 6047, Parlamento Soruşturmas1.

${ }^{35}$ FO 371/7883 E 6210/27/44, Parlamento Soruşturmas1.

${ }^{36}$ FO 371/7883 E 6231, Parlamento Soruşturmas1.

${ }^{37}$ FO 371/7883 E 6269, Parlamento Soruşturmasi.
} 
Majestelerinin Hükümetinin aldığı bilgiye göre Yunanlılar Samsun yakınlarındaki bir kasabayı bombaladılar. İngiliz hükümeti ile Ankara hükümeti arasında diplomatik ilişkiler yoktur.

\section{Ya da 2. Taslak:}

Harmsworth; Samsun'un bombalanmasıla ilgili hiçbir resmi bilgi yoktur. Sadece İstanbul'daki Türk hükümeti ve Ankara'daki Büyük Millet Meclisi can ve mal kaybını bildirmiştir. $^{38}$

Oysa 4 Temmuz 1922'de İstanbul'daki İngiliz Yüksek Komiseri Henderson tarafından Dışişlerine gönderilen bir şifre telgrafinda şu bilgilere yer verilmektedir:

"Samsun'un bombalanmasından önce buradaki insanlara sığınak aramaları için iki saatlik bir uyarı süresi verilmişti. Bombalamadan sonra yaralananların sayısı az idi. Türk basınında Müslümanlara ait $28 \mathrm{ev}$, Hristiyanlara ait $15 \mathrm{ev}$, Ermenilere ait $13 \mathrm{ev}$ tahrip edilmişti. Dört ölü, üç yaralı vardır." 39

$\mathrm{Bu}$ arada Türk kaynaklarında ölen 4 kişi ile yaralanan üç kişinin de Türk olduğu açıklanmaktadır. ${ }^{40}$

Samsun'un bombalanması olayını Türk tarafı müttefikler nezdinde protesto etti. Türk hükümeti tarafından verilen notaya Fransız ve İtalyan temsilcileri Yunanistan'ı uyaracakları ve Yunan donanmasının İstanbul'dan çıkarılmasını isteyecekleri şeklinde cevap verirken, İngilizler oralı bile olmadılar.

Yunanlıların ise bombardıman sonrası amaçlarına ulaştıkları söylenemezdi. Bombardımanda Samsun'un İstiklal Savaşı için yürüttüğü fonksiyonu yok edemediler. Bombalama olayları esnasında bir miktar insani ve maddi zarar açılmış olmasına rağmen Batı Cephesi'ne sağlanan yardım ve bunun nakliyatı durdurulamadı. Yunanlıların Anadolu'da tutunması da sağlanamadı. ${ }^{41}$

Ancak bütün bu gelişmeler karşısında İngiliz Hükümetinin tutum ve davranışlarının tarafsız olduğu söylenemez. Dişişlerine çekilen birçok telgrafa ve sunulan bir o kadar raporlara rağmen olayları ya bilmemezlikten gelmiş, yada duyarsız davranmıştır.

Fakat Samsun'un bombalanması olayları bölgedeki Pontus meselesini doğrudan etkilemiştir. Özellikle 1921 'deki ilk bombalama olayından sonra bölgedeki Rum çetelerinin faaliyetlerini durdurmada zorluk çeken Türk yönetimi Rumların iç bölgelere şevkine karar verrmiştir. Birçok İngiliz ve Amerikan raporlarında bu hususta Türk tarafının haklı olduğu vurgulanmıştır. Yunanlıların bu davranışının saçma ve hukuksuz olduğu belirtilmiştir.

\section{Kaynakça}

\section{ATAŞE Arşivi}

ÎSH, K. 629, G. 110, B. 110-1.

Black Book: The Tragedy of Pontus (1914-1922), Atina, 1922.

DOĞANAY, Rahmi, Milli Mücadelede Samsun'un Önemi ve Samsun Bombardımanı, Samsun, 1993.

\footnotetext{
${ }^{38}$ FO 371/7883 E 6269, Parlamento Soruşturmas1

${ }^{39}$ FO 371/7884 E. 6830/27/44/ section 2.

${ }^{40}$ Orhan Duru, Amerikan Gizli Belgelerinde Türkiye'nin Kurtuluş Yılları, İstanbul 1978.

${ }^{41}$ Rahmi Doğanay, a.g.e., s. 58.
} 
DURU, Orhan, Amerikan Gizli Belgelerinde Türkiye’nin Kurtuluş Yıllarl, İstanbul 1978.

GÜLER, Ali, Sorun Olan Yunanlılar ve Rumlar, Ankara, 2003.

NUTKU, Emrullah, “ Samsun Bombardımanı ve kahramanlık Yarışı”, Yakın Tarihimiz, Cilt IV, Sayı:41, s. 59.

OKUR, Mehmet, Milli Mücadele'de Karadeniz Bölgesine Yönelik îngiliz Faaliyetleri, Ankara, 2006

ŞİMŞİR, Bilal, İngiliz Belgelerinde Atatürk III, Ankara, 1979.

US ARCHIVES NARA

m 363, Roll3; 767-68/98.

M 353, Roll 7.

M 363, Roll 3, 767-68/143 no:401.

M 363, Roll 3, 767-68/142 no:11673.

m 353, Roll 9, no: 299, Amiral Bristol'ün Dışişleri Bakanlığına yazdığı rapor.

C 48, Part 2, Class 805, Volüme 21, Amerikan Konsolosluğu, Samsun, 021.

$767-68 / 269$.

UK ARCHIVES (The National Archives)

FO 608/89.

FO 371/4158, H.s no: 6 .

FO 371/7878, War Office, E 5674/19/44

FO 371/7878 War Office, E 5674/19/44

FO 371/7883, E. 5839/27/44, Eastern Turkey.

FO 371/7884 E. 6830/27/44.

FO 371/788Z E. 6830/27/44/Section 2.

FO 371/7883, no: 271.

FO $371 / 7883$ E, 6311/27/44

FO $371 / 7884$ E, 5840/27/44

FO 371/7883 E, 6101/27/44 no: 219

FO 371/7883 E 6047, Parlamento Soruşturmas1.

FO 371/7883 E 6210/27/44, Parlamento Soruşturmas1.

FO 371/7883 E 6231, Parlamento Soruşturmas1.

FO 371/7883 E 6269, Parlamento Soruşturmas1.

FO 371/7884 E. 6830/27/44/ section 2.

FO 371/7878, E 5674/19/44,War Office. 
Ingiliz ve Amerikan Belgelerinde Samsun'un Bombalanması Olayı ve Pontus Meselesi

WUARIN, Albert, The Mortydrom of The Pontus and International Public Opinion, Cenevre, İsviçre, 1922. 